\title{
THE NUCLEAR TABOO AND THE INTERNATIONAL CAMPAIGN TO ABOLISH NUCLEAR WEAPONS
}

\author{
O TABU NUCLEAR E A CAMPANHA INTERNACIONAL PARA ABOLIR AS ARMAS \\ NUCLEARES
}

Matthew Bolton

Pace University - New York City

E-mail: mbolton@pace.edu

Convidado

\begin{abstract}
ABASTRACT: This article uses Mary Douglas' landmark theorization of purity and danger to explore the development of the 'nuclear taboo' and ICAN's creative manipulation of discourses of nuclear pollution. ICAN placed people who had long been marginalized by nuclear diplomacy survivors, women, indigenous people, civilians, representatives of small states - at the center of the conversation about nuclear weapons. In doing so, ICAN deconstructed discourses legitimating nuclear weapons, revealing the ambivalence and fear underneath diplomatic euphemism. ICAN also turned the stigma associated with nuclear weapons onto those who defended them. I conclude by reflecting on the importance in being transparent about how pariah status for a weapon is socially constructed. Openly discussing the process of stigmatization need not undermine or delegitimize it. Rather, seeing pariah status as a political process enables us to have a conversation about how to address threats to human security without resorting to coercive control.
\end{abstract}

Keytwords: Nuclear Weapons; International Campaign to Abolish Nuclear Weapons; Disarmament and International Security; Human Security.

RESUMO: Este artigo usa a teorização de Mary Douglas' marco de pureza e perigo para explorar o desenvolvimento do tabu nuclear " e a manipulação criativa do ICAN de discursos de poluição nuclear. A ICAN colocou no centro da conversa sobre armas nucleares pessoas que tinham sido marginalizadas pela diplomacia nuclear - sobreviventes, mulheres, povos indígenas, civis, representantes de pequenos estados - . Ao fazê-lo, a ICAN desconstruiu discursos legitimando armas nucleares, revelando a ambivalência e o medo sob o eufemismo diplomático. A ICAN também transformou o estigma associado às armas nucleares naqueles que as defendiam. Concluo, refletindo sobre a importância de ser transparente sobre a forma como o estatuto de paria de uma arma é socialmente construído. Discutir abertamente o processo de estigmatização não precisa minar ou deslegitimar. Em vez disso, ver o estatuto de pária como um processo político permitenos ter uma conversa sobre como abordar as ameaças à segurança humana sem recorrer ao controlo coercivo. 
Palavras-chave: Armas Nucleares; Campanha Internacional de Abolição de Armas Nucleares; Desarmamento e Segurança Internacional; Segurança Humana.

\section{INTRODUCTION}

In July 2017, 122 countries adopted the Treaty on the Prohibition of Nuclear Weapons (TPNW) at the United Nations in New York. Establishing a categorical prohibition, the TPNW builds on the nascent taboo against nuclear weapons, placing them in the same legal category as other pariah weapons. International humanitarian law, which governs the use of violent force, prohibits weapons and tactics that cause unnecessary suffering, are indiscriminate or disproportionate. States have banned Weapons of Mass Destruction (WMD) like chemical and biological weapons, as well as blinding lasers, landmines, cluster munitions, rape and torture, framing them as inhumane pariahs - mala in se or 'evil in themselves' - never justifiable in warfare, no matter how extreme the circumstances. The TPNW culminated a global advocacy effort by the International Campaign to Abolish Nuclear Weapons (ICAN), which received the 2017 Nobel Peace Prize for work to draw attention to the 'catastrophic humanitarian consequences of any use of nuclear weapons' and 'ground-breaking efforts' to achieve the TPNW (Nobel Media, 2017).

ICAN's leaders were aware of the constructivist, feminist and post-structuralist academic literature on the stigmatization of weapons. They self-consciously adopted a discursive strategy casting nuclear weapons (and those who defended them) as immoral pariahs. ICAN persuaded nonnuclear-armed states to move forward with negotiating the TPNW despite a boycott by nucleararmed and -allied states. ICAN argued that the treaty's power would not derive from coercive surveillance and interdiction mechanisms, but rather from its normative power (Bolton and Minor 2016; Fihn, Bolton \& Minor 2017).

This article uses Mary Douglas' landmark theorization of purity and danger to explore the development of the 'nuclear taboo' and ICAN's creative manipulation of discourses of nuclear pollution. ICAN placed people who had long been marginalized by nuclear diplomacy - survivors, women, indigenous people, civilians, representatives of small states - at the center of the conversation about nuclear weapons. In doing so, ICAN deconstructed discourses legitimating nuclear weapons, revealing the ambivalence and fear underneath diplomatic euphemism. ICAN also turned the stigma associated with nuclear weapons onto those who defended them. I conclude by reflecting on the importance in being transparent about how pariah status for a weapon is socially constructed. Openly discussing the process of stigmatization need not undermine or delegitimize it. Rather, seeing pariah status as a political process enables us to have a conversation about how to address threats to human security without resorting to coercive control.

In writing this piece I draw on my participant observation in ICAN's advocacy at the UN since 2014. I have actively engaged in ICAN's work during meetings of the Nuclear NonProliferation Treaty (NPT), the UN General Assembly's First Committee (Disarmament and International Security) and the TPNW negotiations. But I am also an academic analyst of civil society campaigns on disarmament and arms control. This position on the boundary between ICAN and the academy enables me to be a kind of interpreter to both worlds, but nonetheless means I cannot claim to be an objective or neutral observer of ICAN. Instead, I aim for reflexivity and solidarity, casting a sympathetically critical eye over ICAN's advocacy even as I contribute to it myself. 


\section{TABOO AND NUCLEAR WEAPONS}

In her 1966 book Purity and Danger, anthropologist Mary Douglas observed that across cultures and contexts there is no persistent essence of what is considered dirty: 'There is no such thing as absolute dirt: it exists in the eye of the beholder' (1966/2002, p. 2). Rather, an item, person or practice is considered a pollutant only in relation to a 'particular system of classification in which it does not fit' (p. xvii). 'Ambiguous things,' Douglas writes, cause 'cognitive discomfort' and 'seem very threatening' (p. xi). When we find 'matter out of place' (p. 44) transgressing the boundaries that gives us meaning, we 'denounce it by calling it dirty and dangerous' (p. xi). The taboo that builds around the dirty object or behavior operates by threatening contagious harm that spreads 'indiscriminately on contact', extending 'the danger of a broken taboo to the whole community' (p. xiii). Since ideas about dirt derive from underlying shared cultural codes that 'are public matters', they 'cannot so easily be subject to revision' (p. 48). Pollution taboo thus protects 'consensus on how the world is organized', 'shores up wavering certainty' and 'reduces intellectual and social disorder' (p. xi).

Our relationship to dirt is thus profoundly ambivalent; how we respond to the ontological threat it poses reveals much about our cultural, social and political order (Bolton et al. 2016). Douglas finds that rules about dirt 'will be as repressive as the leading members of the society want them to be' (2002, p. xiii). Because purity codes are socially-constructed, they remain malleable. When 'controllers of opinion want a different way of life, the taboos will lose credibility and their selected view of the universe will be revised' (p. xiii). Even while maintaining a taboo, we can choose how to react to disturbing anomalies, including ignoring, reducing, controlling, avoiding, condemning them (pp. 48-49). More positively, dirt 'can be used in ritual...poetry and mythology...to enrich meaning or to call attention to other levels of existence' (p. 49). Many cultures also have rituals such as washing which integrate an anomalous person or object, moving them from 'unclean' to 'clean', 'unbeliever' to 'baptized', 'profane' to 'consecrated', 'defiled' to 'holy' (pp. 40-45). When societies choose to 'deliberately confront the anomaly' (p. 48), the provocation of an object, person or behavior in the wrong place can create powerful impetus for social change, creating 'a new pattern of reality in which it has a place' (p. 48). As such, 'pollution beliefs can be used in [the] dialogue of claims and counterclaims' in political life (p. 4).

We can apply Douglas' insights to nuclear weapons' place in the fabric of norms that give meaning to the international order. Nuclear weapons are a scandalous anomaly, violating the standard classifications states use to justify their monopoly on the legitimate use of force. International humanitarian and human rights law encodes certain forms of violence as barbaric, uncivilized and inhumane, enabling states to claim their use of force is rule-governed and restrained by principles of humanity (Mathur 2011). However, nuclear weapons contravene the core principles of these legal norms. They are indiscriminate, disproportionate, cause unnecessary suffering, violate the public conscience and core rights to life, health, shelter, food and a clean environment (Fihn et al 2013). Unsurprisingly then, international society has developed a 'nuclear taboo', making the use of nuclear weapons essentially forbidden by custom (Tannenwald 2005 \& 2007; Sauer 2015). Only nine of 193 UN member states have stockpiled nuclear weapons. States have also negotiated a series of instruments limiting nuclear weapons testing and proliferation. The 1968 NPT carved out an exception to the nuclear taboo for the five original nuclear-armed powers. However, ongoing possession was predicated on making good faith progress towards disarmament. A la Douglas, the anomaly of the Nuclear Weapons States was accommodated as long as they promised to reduce and end nuclear weapons' symbolic pollution of the international order. Establishing nuclear weapons as anomalous has, however, also imbued them with an especial 
discursive power. de Santana (2009) and Ritchie (2013) argue that the great powers have fetishized nuclear weapons, the ultimate symbols of status in the international system. In his ethnography of American weapons' scientists, Gusterson (1998) found deep reverence for the Bomb, in which a cult of secrecy provided a sense of order and periodic nuclear tests were perceived as rituals of renewal and rejuvenation.

To allay and repress outrage at the persistence of nuclear stockpiles, officials and apologists have accreted complex layers of discursive legitimation onto nuclear weapons. In the right hands, they assert, nuclear deterrence ensures the stability of the international order by raising the cost of war. This article of faith remains remarkably durable in the face of considerable contrary empirical evidence (e.g. Wilson, 2013; Schlosser 2013). But rigorous analysis of the efficacy of nuclear deterrence is stymied by media silence, secrecy, and blanket, often absurd, government denials (e.g. Bolton 2015). More subtly, technocratic discourse mystifies discussions of nuclear weapons, preserving them for an initiated 'nuclear priesthood' (Cohn 1987; Ghamari-Tabrizi 2005). The nuclear-armed states and their allies make rhetorical commitments to a 'world free of nuclear weapons', going through the reassuring rituals of arms control talks. However, the structure of these conversations ensures that countries with nuclear arsenals remain in control (Myrdal 1997). Dissenting voices - survivors, indigenous peoples, diplomats from smaller states, the Global South, women and civil society - are systematically marginalized from the most important discussions.

Anxiety about nuclear arms remains pervasive, but the nuclear weapons complex has displaced the nuclear taboo onto two images of the Other: the abject victim and the rogue proliferator. Occurring in 'remote' areas, nuclear testing created 'no-go areas' contaminated by radiation. Survivors of nuclear weapons - called hibakusha in Japan - are thus isolated from global policy arenas in which nuclear weapons are discussed. Many also face considerable social stigma. As a result, through the vector of fallout, the pollution associated with nuclear weapons is transferred from the weapon onto those who are victim to it. In many nuclear policy conversations I have observed, victims' presence - when allowed at all - is carefully managed, either through the display of images of injured bodies or testimony focused on suffering. Survivors are rarely enfranchised as full agents, presented as apolitical objects of pity rather than contributors of policy ideas (c.f. Kapoor 2004). The proliferator is discursively framed as having agency, but only in a malevolent form. When states outside the legitimated nuclear club pursue nuclear weapons, their actions are framed as 'rogue', rather than security-seeking, behavior. The figure of absolute evil is the nuclear terrorist, utterly irrational and incapable of being deterred. Gusterson (1999) and Biswas (2014) argue that the discourse of nonproliferation distracts policy attention from the tremendous dangers posed by the existing arsenals of the nuclear powers, essentially transferring the anxieties produced by the nuclear taboo onto a scapegoated pariah (c.f. Girard 2001). The major military powers and their allies are willing to go to extensive efforts to prevent proliferation to rogue states and non-state actors, wielding the sanctioning power of the UN Security Council, establishing intrusive inspections regimes and, in the case of Iraq, even invasion.

Counterintuitively then, the dominant policy discourse on nuclear weapons has established a place in the international order for the ultimate matter out of place. It has laundered, even baptized, nuclear weapons, suggesting that when they are in the 'right hands', nuclear weapon are not a source of pollution or danger. Rather, by establishing a 'nuclear peace' (Waltz 1983), the almost 15,000 nuclear warheads worldwide supposedly keep us safe at night. To paraphrase Strangelove, nuclear discourse teaches us 'to stop worrying and love the Bomb.'

\section{ICAN'S MOBILIZATION OF TABOO}


Douglas argued that pollution taboos do not necessarily have to be oppressive or unthinking:

In chasing dirt, in papering, decorating, tidying, we ... are positively re-ordering our environment, making it conform to an idea. There is nothing ... unreasoning in our dirt-avoidance: it is a creative movement, an attempt to relate form to function, to make unity of experience. (p. 3).

Similarly, ICAN's advocacy seeks to positively reorder the global nuclear environment, making it conform to ideas of humanitarianism, human rights and environmentalism. To persuade states to refashion the international nuclear taboo, ICAN has enacted a series of discursive moves, each of which meets with countermoves from the nuclear-armed and nuclear-allied states.

ICAN sought to contest the silencing of information counter to the dominant nuclear narrative. At the 2013 and 2014 international conferences on the humanitarian consequences of nuclear weapons, held in Oslo, Nayarit and Vienna, ICAN helped non-nuclear-armed states amplify the marginalized testimony of scientists, humanitarian agencies and survivors. Nucleararmed and -allied states tried to dismiss this new evidence through boycotting sessions, blanket denial and suggesting that humanitarianism must be 'balanced' against national security concerns. However, the conferences proved sufficiently convincing to the majority of states that the humanitarian consequences were themselves a threat to 'human security for all' (Vienna Conference 2014). They sought to revitalize Article 6 of the NPT, which places legal obligations on all states parties - not just the Nuclear Weapons States - to pursue 'effective measures' for 'nuclear disarmament.' (See: Minor 2015).

ICAN aimed at "puncturing the "mystique" of nuclear weapons (Fihn, 2012), questioning the view that, as one campaigner put it to me, 'nuclear weapons have some sort of inherent, magical value that other WMD do not have.' ICAN undermined nuclear apologists' claims to 'realism' by questioning the often fantastical claims about nuclear weapons, easily debunked by the scientific data emerging from the Oslo, Nayarit and Vienna conferences. While ICAN deconstructed the specialness of nuclear weapons, the campaign simultaneously sought to 'enhance the stigma that already exists' (Acheson 2014, p. 25) by recoding them as pariah weapons under international humanitarian law. One ICAN advocate described this strategy as framing nuclear weapons as 'not a magic Other, but a really bad Other.' ICAN activists thus deployed moral, ethical and religious arguments to establish nuclear weapons as mala in se, instruments of unconscionable evil. This approach is now enshrined in the TPNW, whose the preamble frames nuclear weapons in language of the humanitarian tradition as 'abhorrent to the principles of humanity and the dictates of public conscience' and refers to the 'ethical imperatives for nuclear disarmament.'

Nuclear-armed and -allied states have responded by suggesting the TPNW's good intentions will have little impact on rogue actors like North Korea and so should be balanced by 'pragmatic' attention to strategy stability. As a result, ICAN repeatedly asserts that there are 'no safe hands for a nuclear weapons', pointing to the record of accidents and close calls. The campaign has showcased testimony by survivors of the harm caused by nuclear weapons use, testing and production, showing how the pursuit of a nuclear-armed national security has come at the cost of the human security of victims. ICAN has also redirect the stigma associated with those marginalized from the nuclear policy conversation onto those who defend the nuclear arsenal. They describe nuclear armed states as the source of past and future polluting fallout. They call out diplomats for having 'blood on their hands.' ICAN activists cast the nuclear-allied states as 'weasels' (literally inhuman) so often that I have heard diplomats from those countries adopt the moniker themselves. 
The advent of stigmatized people and discourse into the nuclear policy conversation has generated considerable anxiety among representatives of nuclear-armed and -allied states. The Belarussian delegate to the Conference on Disarmament expressed concern that increasing access for civil society would result in 'topless ladies screaming from the public gallery throwing bottles of mayonnaise' (Charbonneau, 2015). I have heard diplomats from nuclear-armed states suggest that advocates for the TPNW might make nuclear war more likely. The absurdity of these fears points to underlying taboos against pollution of the policy arena by the 'wrong people.' Their arrival generates a political moment that unsettles the technocratic sterility of the nuclear conversation. As policymakers react erratically to the changed conversation, they undermine a key legitimating claim - that they are the cooler, more rational heads. As they lose the affective contest to TPNW-supporting states and activist, nuclear apologists have begun to critique ICAN for charging the policy arena with emotional appeal. At a recent multilateral nuclear disarmament meeting I attended, a diplomat from a nuclear-allied state chided an ICAN representative for 'politicizing' the testimony of the hibakusha. ICAN activists respond to such critiques by saying they want survivors to be full agents, able to be political, not treated as angelic symbols of suffering.

\section{CONCLUSION}

ICAN's self-aware refashioning of the nuclear taboo draws attention to stigmatization processes in international politics. Deploying discursive disapproval and the pollution taboo alerts us to the possibilities of social sanctioning of states as an alternative to militarized modes of nuclear nonproliferation. In her analysis of the anti-slavery norm, Julia O'Connell Davidson argues that in obscuring the socially constructed boundary around what is considered mala in se, we shut down political space that can enable us to see how taboo practices are connected to much broader social processes (2010). Therefore, by being open about the process of ICAN's taboo construction, I aim to be transparent about, rather than obfuscate, what we have done. This means giving up the notion of some determined essence of nuclear weapons that 'naturally' places them in a category of inhumane weapons. But this avoids the trap of attaching to nuclear weapons an unthinking association with supreme evil that is easily displaced onto Others to be repressed or even eliminated through intrusive surveillance, blanket sanctions and military intervention. It also enables us to link the ban on nuclear weapons to a broader emancipatory effort to stigmatize and constrain militarism. The factors and functions that have drawn the world's opprobrium to nuclear weapons can be seen and condemned in more 'conventional' weapons and military practices.

\section{REFERENCES}

Acheson, R., T. Nash \& R. Moyes. (2014) A Treaty Banning Nuclear Weapons: Developing a Legal Framework for the Prohibition and Elimination of Nuclear Weapons. New York, Article 36 \& Reaching Critical Will.

Biswas, S. (2014) Nuclear Desire: Power and the Postcolonial Nuclear Order. Minneapolis, University of Minnesota Press. 
Bolton, M. (14 May 2015) "No New Information on the Consequences of Nuclear Weapons? Deconstructing Nuclear Discourse at the 2015 Nuclear Non-Proliferation Treaty Review Conference.” NPT News in Review. 13(10). p. 7. <https://goo.gl/VMHa4n>.

Bolton, M. \& E. Minor. (2016) 'The Discursive Turn Arrives in Turtle Bay: The International Campaign to Abolish Nuclear Weapons' Operationalization of Critical IR Theories.' Global Policy. 7(3). pp. 385-395.

Bolton, M., S. Froese \& A. Jeffrey. (2016) “"Go get a job right after you take a bath”: Occupy Wall Street as Matter Out of Place.' Antipode. 48(4). pp. 857-876.

Charbonneau, L. (2015) 'Belarus diplomat worries topless, mayo-throwing women could disrupt U.N.' Reuters. <http://www.reuters.com/article/us-un-belarus-mayonnaiseidUSKBNOLF2MA20150211>.

Cohn, C. (1987) 'Sex and Death in the Rational World of Defense Intellectuals.' Signs. 12(4). pp. 687-718.

de Santana, A. H. (2009) 'Nuclear Weapons as the Currency of Power: Deconstructing the Fetishism of Force', Nonproliferation Review, 16 (3). pp. 325-345.

Douglas, M. (2002) Purity and Danger: An Analysis of Concepts of Pollution and Taboo. Routledge Classics Edition. New York, Routledge Classics.

Fihn, B. (2012) 'About a Ban', ICAN Campaigners Kit. <http://www.icanw.org/wpcontent/uploads/2012/08/Campaigners-Kit-Pernilla_final2.pdf>.

Fihn, B. (ed.) (2013) Unspeakable Suffering: The humanitarian impact of nuclear weapons. Geneva, Reaching Critical Will.

Fihn, B., M. Bolton \& E. Minor. (2017) 'How We Persuaded 122 Countries to Ban Nuclear Weapons.' Just Security. <https://www.justsecurity.org/46249/persuaded-122-countries-bannuclear-weapons/>.

Ghamari-Tabrizi, S. (2005) The Worlds of Herman Kahn: The Intuitive Science of Nuclear War. Cambridge, Harvard University Press.

Girard, R. (2001) I See Satan Fall Like Lightning. Maryknoll, Orbis Books.

Gusterson, H. (1998) Nuclear Rites: A Weapons Laboratory at the End of the Cold War. Berkeley, University of California Press.

Gusterson, H. (1999) 'Nuclear Weapons and the Other in the Western Imagination.' Cultural Anthropology. 14(1). pp. 111-143.

Kapoor, I. (2004) 'Hyper-self-reflexive development? Spivak on representing the Third World "Other", Third World Quarterly, 25 (4), pp. 627-647. 
Mathur, R. (2011) 'Humanitarian Practices of Arms Control and Disarmament.' Contemporary Security Policy. 32(1). pp. 176-192.

Minor, E. (2015) 'Changing the discourse on nuclear weapons: The humanitarian initiative.' International Review of the Red Cross. 97(899). pp. 711-730.

Myrdal, A. (1977) The Game of Disarmament: How the US and Russia Run the Arms Race. Manchester: Manchester University Press.

Nobel Media. (2017) 'The Nobel Peace Prize 2017.' <https://www.nobelprize.org/nobel_prizes/peace/laureates/2017/>.

O'Connell Davidson, J. (2010) 'New slavery, old binaries: human trafficking and the borders of "freedom."' Global Networks. 10(2). pp. 244-261.

Ritchie, N. (2013) 'Valuing and Devaluing Nuclear Weapons', Contemporary Security Policy, 34 (1). pp. 146-173.

Sauer, F. (2015) Atomic Anxiety: Deterrence, Taboo and the Non-Use of U.S. Nuclear Weapons. New York, Palgrave Macmillan.

Schlosser, E. (2013) Command and Control: Nuclear Weapons, the Damascus Accident, and the Illusion of Safety. New York, Penguin.

Tannenwald, N. (2005) 'Stigmatizing the Bomb: Origins of the Nuclear Taboo.' International Security. 29(4). pp. 5-49.

Tannenwald, N. (2007) The Nuclear Taboo: The United States and the Non-Use of Nuclear Weapons since 1945. Cambridge, Cambridge University Press.

Vienna Conference. (2014) 'Pledge on the Humanitarian Impact of Nuclear Weapons.' <http://www.icanw.org/wp-content/uploads/2015/03/HINW14vienna_Pledge_Document.pdf>.

Waltz, K.N. (1983) 'Toward Nuclear Peace.' In: Strategies for Managing Nuclear Proliferation. D.L. Brito, M.D. Intriligator \& A.E. Wick (Eds.). Lexington, Lexington Books. pp.117-134.

Wilson, W. (2013) Five Myths about Nuclear Weapons. New York, Houghton Mifflin. 